\title{
Poetics Of The Ghazal Genre In Uzbek Poetry Of The Second Half Of The XX Century
}

\author{
Shahnoza Muhitdinovna Rakhmonova \\ Alisher Nava'i Tashkent state university of the Uzbek language and literature, \\ PhD, Senior teacher \\ shahnoza@navoiy-uni.uz
}

\begin{abstract}
The article reveals the role of the ghazal genre in the development of poetic form and content in Uzbek poetry in the second half of the twentieth century. The poems of Uzbek poets Habibi, Sabir Abdulla, Chustiy, Charkhiy, Erkin Vahidov, Abdulla Aripov are the basis for the analysis. The main theme of the article is to cover the issues related to the prosody characteristics and content of the simple ghazal, ghazal-i qit'a, ghazali musajja', ghazali muvashshahi ta'rikh and reversible ghazal metre in the works of these artists. It also discusses ghazal muvashshahi ta'rikh, which are not found in the history of Uzbek literature, and the possibilities of ghazal types with reversible prosody are analyzed.
\end{abstract}

Keywords:

aruz, prosody, genre, ghazal, simple ghazal ghazal-i qit'a, ghazali musajja', ghazali muvashshahi ta'rikh, reversible ghazal metre.

Article Received: 18 October 2020, Revised: 3 November 2020, Accepted: 24 December 2020

\section{Introduction}

The second half of the twentieth century Uzbek poetry, with its content, forms of expression and artistic means, forms a special stage in the history of Uzbek literature. During this period, the main focus of poetry was on depicting changes in life and people's thinking in their entirety. Indeed, "Uzbek literature of the twentieth century has established a strong connection with the life of the people and society. Such a connection did not exist in the earlier stages of our literature. The Uzbek literature of the XX century has led the people and society in their pursuit of freedom and national development, and has achieved certain successes in this endeavor"

During this period, Uzbek poetry rose to a new level in terms of poetic form and genre, language and style. Along with traditional poems written in barmoq prosody, poetic forms such as ghazal, rubai, tuyuk and muhammas, which are

\footnotetext{
${ }^{1}$ Karimov N. XX asr mening taqdirimda // Jahon adabiyoti.

- T., 2001. - № 1. - B. 24.
}

the main poetic genres of our classical literature, were widely used.

Poets of this period, such as Zokirjon Kholmuhammad oghli Habibi, Sabir Abdulla, Nabikhuja Nurillakhuja oghli Chustiy, Askarali Charkhiy, Erkin Vahidov, Abdulla Aripov, Jamol Kamol, Matnazar Abdulhakim were masters of their craft indeed. Their work stands out as a bridge that connects the traditions of classical literature with modern literature. In the poetry of these artists, we see that along with the collections of poems created at the prosody of a barmoq, there are also divans written in the system of classical genres such as ghazal, rubai, tuyuq and mukhammas.

It is known that one of the most important and basic element of a poetic work is prosody, which "gives a unique method (rhythm) to the lines in the poem" 2 . The study of the poetic dimension of the works of our classical artists

\footnotetext{
${ }^{2}$ Rustamov A. Aruz haqida suhbatlar. - T.: Fan, 1972. - B. 3.
} 
shows that our poets have chosen the prosody in each poem according to the idea and image in the work. "For example, deep philosophical observations about life and society, man and love, the fate of the poet, the sufferings of emigration are expressed in calm, prosodies, whereas the description of the beloved, the passionate experiences of the lover are combined in lighter, more attractive verses, fidelity and devotion is sung in verses based on a playful rhythm"3.

One of the main factors determining the prosody of a poetic work is the lyrical genre. When an artist chooses prosody for a particular work, he also considers in which genre it will be created, because each genre will have its own prosody range. Some genres have a wide range of prosody possibilities, they can be written in any prosody of the application system, and some genres within a predetermined prosody.

One of the genres with wide prosodic opportunities is a ghazal. It is quite a challenge indeed trying to find a poet of a classical literature who was not able to create in this genre. The Turkish ghazal, which began with Nasiruddin Rabguzi's Qisasi Rabguzi, has gone through many centuries of development. In this article, we focus on the poetics of ghazals in Uzbek poetry of the second half of the twentieth century.

\section{The main part}

\section{Ghazal and its types.}

It is known that ghazal is an Arabic word that literally means "to flatter a woman", "to fall in love". "Ghazal is one of the unique genres in Oriental literature. It was formed on the basis of Arabic literature and later developed very strongly in the Persian and Turkish environments. Alisher Navoi is the author who made Uzbek literature reach its zenith"5. The first stanza of the ghazal is

\footnotetext{
${ }^{3}$ Hojiahmedov A. Furqat aruzi / Furqat ijodiyoti. - T.: Fan, 1990. - B. 83.

${ }^{4}$ Baranov X.K. Arabsko-russkiy slovar-M.: Nauka, 1958. - C. 721 .

${ }^{5}$ To'xliev B. G'azal va uni tahlil qilish metodikasi /

ALISHER NAVOIY VA XXI ASR (xalqaro ilmiy-nazariy
}

called matla 'and the last stanza is called maqta'. The poet's nickname is often used in maqta'. Starting with the first Uzbek ghazal composing most of them were created in the ramal prosody. Odiljon Nosirov, Dilnavoz Yusupova emphasizes that there are several types of ghazals in literature and distinguishes ten forms. Accordingly there are the following classifications of a ghazal in literature ${ }^{6}$ :

1. Simple or ordinary ghazal (rhyme: aa, ba, ca, da...);

2. Ghazali husni matla' (rhyme: aa, aa, ba, ca...);

3. Ghazali qit'a (rhyme: ba, ca, da...);

4. Ghazal musajja '(internal rhyme is used from the second stanza);

5. Ghazali mulamma (two or more languages are applicable within the lines);

6. Ghazali muvashshah (name or word is derived from the capital letters of a stanza or verse);

7. Ghazal mushaira (based on the recitation of ghazals by two or more poets through poetic competition);

8. Ghazali zulqofiyatayn (based on doublerhyme);

9. Ghazali zulradifayn (based on double-radif);

10. Ghazali zebqofiya (rhyme: aa, aa, aa, aa...)

Among the types of ghazals mentioned in Uzbek poetry in the second half of the XX century, simple ghazal, ghazali qit'a, ghazali musajja, ghazali muvashshah, ghazali zulqofiyatayn are of the most common ones.

Simple or ordinary ghazals, rhymed in the form aa, ba, ca..., are the most common among the types of ghazals. In the second half of the twentieth century, the classical tradition was continued in Uzbek poetry. In particular, the Uzbek poet Abdulla Aripov's ghazal "To seni" was created in the form of this simple or ordinary ghazal. It is known that prayer ghazals are a series

anjuman materiallari). - T.: MASHHUR-PRESS, 2019. - B. 239.

${ }^{6}$ See : Nosirov O. va boshq. O'zbek klassik she'riyati janrlari. - T.: O‘qituvchi, 1979; Yusupova D. Aruz va mumtoz poetika asoslari. - T.: Akademnashr, 2020. - B. 199. 
of ghazals that express the meaning of asking Allah for salvation. Ramali musammani mahzuf prosody is extremely convenient for the use of ghazals in the content of maqta' or supplication. Many poets have written poems in this prosody.

The poet addresses Allah by choosing the radif "seni" in his poem "To seni", and seeks the quality of unity from people or other servants until he feels it in his heart. In fact, while emphasizing that loneliness is unique to itself, he admits that he came to know the world after recognizing Allah, and that he understood himself after realizing his loneliness:

\section{Kimnidir tanho dedim men}

Topgunimcha to Seni,

Vo ajab, dunyoni topdim,

Anglagach tanho Seni.

The radif "seni" chosen for the ghazal also paved the way for him to choose his prosody. After all, the word "to seni" corresponds to the foilun network of the ramal prosody.

Erkin Vahidov's muzori is distinguished by the richness of the ghazal metaphors "Ghuncha" written in the prosody of the muzorii musammani ahrab $(--\mathrm{V} /-\mathrm{V}--/--\mathrm{V} /-\mathrm{V}--)$. The composition of the ghazal is based on the interaction of the lover and the bud, which is just about to open. Only true lovers, lovers and beloveds who are filled with the light of divine love in their hearts, can find a miracle in everything they see. The first stanza of the ghazal begins with the expression of the desire of the lover, who is looking for his close friend, to be in love with the "bud that gently looks from under the leaf" in the flower of love:

\section{Bud that gently looks}

\section{From under the leaf,}

What a secret you keep

Why is your leaf rolled up $?^{7}$

This prosody has a small rhythmic pause within the line. That is, after both syllables (mafuvlu, mafoiylun) there is a small pause in the

\footnotetext{
${ }^{7}$ Habibiy. Devon. - T.: G'afur G'ulom nomidagi Adabiyot va san'at nashriyoti, 1975. - B. 180.
}

verse, which is directly due to the equality of the syllable with the word, in other words, the division between the syllables, like a syllabicmetered verse, leads to an attractive melody. in this respect it is reminiscent of the meters of the Hazaj prosody in this direction.

Uzbek writer Chustiy's ghazal that starts with "Sadaghang bulay nigorim" is a sample of ghazali qit'a. "Ghazali qit'a is alike to a qit'a. The text of such a ghazal will not be as rhyming as on the qit'a. That is why the qit'a is called the ghazal or the ghazali qit'a"8. It combines the features of a ghazal and a qit'a. While the ghazali qit'a has a pseudonym, it covers many topics like ghazal and is reminiscent of ghazal in terms of volume possibilities, while the presence of rhyme in only a couple of verses, like the ghazal, brings it closer to the qit'a. In this sense, the ghazali qit'a genre can be called the ghazal and the product genre between the qit'as.

Ghazali qit'a is is a rare however occurring genre in some of the works of Uzbek poets. They were extremely rare in the medieval literature. Only a handful of artists have addressed this type of ghazal. The ghazali qit'a genre was first observed in the works of Babarahim Mashrab, and later in the works of Almai, Hamza, Sabir Abdullah. Chustiy continued this tradition, "Sadaghang bulay nigorim" is a beautiful illustration of the genre composed in the prosody ramali musammani mashkul. But the poet used the words in it so skillfully that, as a result, this prosody, which is considered to belong to a complex sounding, became playful in Chusty's ghazal. As an example, we give 2 stanzas of the ghazali qit'a:

\section{Seni yayratar diyorim, sadaghang bo 'lay, nigorim,}

Qarashing mening madorim, bu tomonga bir qarab qo 'y.

\footnotetext{
${ }^{8}$ Nosirov O. va boshq. O‘zbek klassik she’riyati janrlari. T.: O‘qituvchi, 1979. - B. 72.
} 
Menga yo 'q gunohni ilma, beri kel uzoqqa jilma

Go 'zalim bahona qilma, bu tomonga bir qarab qo ' $y^{9}$.

At the same time, it is necessary to emphasize the importance of the radif as the main factor determining the prosody of the ghazal. The radif "bu tomonga bir qarab qo "y" chosen for the ghazali qit'a also led to the choice of its prosody, ie the radif failotu $(\mathrm{VV}-\mathrm{V})$ of the foilotun $(-\mathrm{V}-$ -) in other words, it requires that the prosody be written in ramali musammani mashkul form. Another factor that provided the cheerful tone of the ghazali qit'a was the vasl phenomenon. It is known that the phenomenon of vasl is the addition of a consonant sound at the end of some closed syllables to this syllable, followed by a syllable that begins with a vowel sound, resulting in the creation of a long syllable out of extra-long syllable, and a short syllable out of long syllable ${ }^{10}$. Considering the $3 \mathrm{rd}$ verse of the ghazal:

\section{Ochiq aytaman bu so 'zni, bilasanmi}

bu ramuzni,

\section{Uyalib qochirma ko 'zni, bu tomonga}

bir qarab qo' $y$.

In the given stanza, the consonant " $q$ " in the open word is combined with the syllable "ay" in the word "aytaman", which comes after it, to form a vowel and is pronounced as "qay". As a result, the tone is light and playful.

As mentioned above, the ghazali qit'a is also found in the poetry of the Uzbek poet Sabir Abdullah. It can be observed that the poet's ghazali qit'a was written in the prosody of ramali musammani makhbuni mahzuf. It is noteworthy that Sabir Abdullah uses the radif "ishlar edik" for this prosody. The radif in the quoted poem corresponds to the verse "- V V -". This in itself requires that the poem be created in a particular poetic form of ramali musammani makhbuni

\footnotetext{
${ }^{9}$ Chustiy. Hayotnoma. - T.: G`afur G'ulom nomidagi Adabiyot va san'at nashriyoti, 1988. - B. 161.

${ }^{10}$ Hojiahmedov A. O‘zbek aruzi lug'ati. - T.: Sharq, 1998. B. 44 .
}

mahzuf, since the last three syllables belong to foilotun form of makhbuni mahzuf ( V V -).

Ghazali qit'a has a biographical character. It depicts the creation process with the poet's contemporaries Ulfat, Anisiy, Bokiy, Mahjur and Habibiy, reflects the processes associated with the reading of classic literature. The author emphasizes that from the very first lines they began to study Hazrat Navoi's "Chor Divan" with great love, and thought of himself and those around him to tourists walking in this wonderful "flower garden":

\section{"Chor devon" gulshani ichra kezibon} bir necha oy,

Qilibon sayru tamosho, tunu kun
ishlar edik.

Bilibon lahzada har satrini biz bir

maktab, ishlar edik ${ }^{11}$.

She'riyat bobida zo 'r kasbu funun

The first stanza of the ghazal is in ramali musammani makhbuni maqsur (foilotun failotun failotun failon $-\mathrm{V}--/ \mathrm{VV}--/ \mathrm{VV}--/ \mathrm{VV} \sim$ ) and the rest is in musammani maxbuni mahzuf (foilotun failotun failotun failun $-\mathrm{V}--/ \mathrm{VV}--$ /VV - -/VV-). The expert of Aruz metre D.Yusupova states "The first stanza of the prosody of the mahzuf (maqsur) of the ramali musammani makhbuni mahzuf (maqsur) can sometimes come in the form of "failotun", ie if the first stanza begins with a foilotun, the next stanza begins with a failotun (or vice versa) belongs to all the prosody in the makhbun network of the prosody"12. In fact, in the above lines, the first and fourth stanzas, that is, the first stanzas are in the network of foilotun $(-\mathrm{V}--)$, the second and third stanzas begin with the failotun ( $\mathrm{V} \mathrm{V}--)$, and this creates a peculiar tone.

In the Uzbek poetry of the second half of the XX century in the poetry of Habibi, Charkhi,

\footnotetext{
${ }^{11}$ Abdulla Sobir. Devon. - T.: Badiiy adabiyot, 1965. - B. 83.

12 Yusupova D. Aruz va mumtoz poetika asoslari. - T.: Akademnashr, 2020. - Б. 29.
} 
Erkin Vahidov there are also beautiful examples of ghazal musajja. Ghazal musajja 'is a type of ghazal in which an internal rhyme is used from the second stanza. This type of ghazal is widely used in the works of Alisher Navoi, Zahiriddin Babur, Boborahim Mashrab. Zahiriddin Babur emphasizes that Alisher Navoi has a special place in the development of the ghazal musajja. Zahiriddin Babur also mentions that Alisher Navoi's ghazal musajja were written mainly in the hazaj $^{13}$. In classical literature, ghazal musajjas were written mainly in ramal, hazaj, rajaz bahrs. Charkhi, on the other hand, created the ghazal musajja in the prosody of the munsarihi musammani matviyi mavquf (muftailun foilun muftailun foilon $-\mathrm{VV}-/-\mathrm{V}-/-\mathrm{VV}-/-\mathrm{V} \sim)$. This is one of the few cases not observed in the history of literature. His ghazal poem "Gulbahor" starts with a stanza:

Bog'u chaman yashnatib, keldi bahor, gulbahor, Mehnat elin shod etib, keldi bahor, gulbahor,

Mavsumi g'oyat go 'zal, suvlari qandu asal, Shavqi-la aylab jadal, keldi bahor, gulbahor ${ }^{14}$.

The poet depicts the coming of spring, the bride of the season, with beautiful allegories. The arrival of spring will brighten the gardens, meadows and delight the hardworking people. It is noted that spring came with very beautiful scenery, with the sweetness of its waters, with its own passion.

Charkhi also skillfully uses the art of tajziya in the first line of the ghazal. Tajziya means to break in Arabic $^{15}$. The poet divided each of the stanza verses into two equal parts, rhyming the first part with the third part and the second part with the fourth part.

Bog'u chaman yashnatib, keldi bahor, gulbahor, Mehnat elin shod etib, keldi bahor, gulbahor.

\footnotetext{
${ }^{13}$ Is'hoqov Yo. So'z san'ati so'zligi. - T.: O'zbekiston, 2014. - B. 114.

${ }^{14}$ Charxiy A. Qiyolab o'tdi. - T.: Akademnashr, 2010. - B. 107.

${ }^{15}$ Yusupova D. Aruz va mumtoz poetika asoslari. - T.:

Akademnashr, 2020. - Б. 261.
}

In Erkin Vahidov's poetry there are also ghazali musajjas. His ghazals "Lola" and "O'tkardim" can be considered as an example of this type.

\section{Ajab, yoshlikni ne qildim - Faqat orzuda o'tkardim. Hayot oldinda deb bildim,} Shu pok tuyg 'uda o 'tkardim.

\section{Hamisha nenidir kutdim,}

Hamisha yo 'lga ko'z tutdim,

Umrning yarmini o'tdim,

Shirin uyquda o 'tkardim ${ }^{16}$.

The ghazak is written in the prosody hazaji musammani solim (mafoiylun mafoiylun mafoiylun mafoiylun $\mathrm{V}---/ \mathrm{V}---/ \mathrm{V}---/ \mathrm{V}$ - - -). In the poem, the poet emphasizes that he spent his youth in a dream and pure feeling that his whole life is ahead, yet to come. Always waiting for something, watching his path, he says he has spent half his life in a sweet sleep. Erkin Vahidov, like Charkhi, skillfully uses the art of tajziya (qildim - bildim, orzuda - tuyg'uda) in the first verse of the ghazal. He also skillfully applies the art of similie (pok tuyg' $u$, shirin uyqu,..).

The least common type of ghazal in Uzbek literature is the ghazali zulqofiyatayn. If the verses of the ghazal are written in two rhymes from the beginning to the end, then such a ghazal is called a ghazali zulqofiyatayn ${ }^{17}$. It first appears in Uzbek literature in the works of Alisher Navoi. In the poetry of the second half of the twentieth century, ghazali zulqofiyatayn was used in the works of Habibi. Here is an example of such a ghazal:

\section{Elga qilib lutfini in'om om Ayladi ko 'p dilni dilorom rom.}

\section{Dona bo 'lur xoli ko 'ngil murg 'iga Qora sochini qilsa gulandom dom.}

\section{Suratini ishq eli, bil ittifoq,}

\footnotetext{
${ }^{16}$ Vohidov E. Tanlangan asarlar. - T.: "SHARQ" NMAK, 2018. - B. 400.

${ }^{17}$ Nosirov O. va boshq. O'zbek klassik she’riyati janrlari. T.: O‘qituvchi, 1979. - B. 83.
} 
Qo 'ydi ko 'rib sarvari asnom nom.

\section{Chiqmagudek bo 'ldi mahim noz etib Abr bila keldi bu oqshom shom.}

Ko 'yi sari gah yiqilib, gah turib, Qo 'ygan edim har qayu hangom gom.

\section{Daf'i xumor etgali kirgan chog 'im,} Topdi bu dayr ichra saranjom jom.

\section{Ko 'rdi, Habibiy, dedi hukm ayladi} Ko 'nglim aro erdi bu ahkom kom ${ }^{18}$.

The effectiveness of the melody is enhanced by the fact that both pairs of rhyming rhymes in the verses are murdaf rhymes made from the original ("o"). Ghazal has a form of musaddasi matviyi mavquf (makshuf) (ruknlari va taqti'i: muftailun muftailun foilon $-\mathrm{V} \mathrm{V}-I-\mathrm{V} \mathrm{V}$ - - $\mathrm{V} \sim(-\mathrm{V}-)$. The sadr, ibtido, hashv of the ghazal is in mustaf'ilun matviy branch - muftailun $(-\mathrm{VV}-)$, and the aruz and zarb are written in matvi branch of the original matviyi makshuf direction foilun $(-\mathrm{V}-)$. This prosody is a very popular measure in our poetry.

During this period, it was observed that among the ghazals written in the target prosody of the ramali musammani maqsur, there was a poem written in the ghazal double muvashshah genre, which is not found in the history of our classical literature. This ghazal was written by Chusty on the occasion of the 70th anniversary of the poet's friend Asgarali Charkhi. The poet himself wrote about it in the "Sadoqat gullari" ("Flowers of Loyalty") divan as a congratulatory message to my dear friend and brother, teacher Asgarali, that is, to the 70th anniversary of Mavlono Charkhi, he said ${ }^{19}$.

There is information in the theoretical literature about the muwashshah type of ghazal. In particular, the book 'O'zbek klassik she'riyati

\footnotetext{
${ }^{18}$ Habibiy. Devon. - T.: G'afur G'ulom nomidagi Adabiyot va san'at nashriyoti, 1975. - B. 216.

${ }^{19}$ Chustiy. Sadoqat gullari. - T.: Vneshtorgizdat, 1992. - B. 121.
}

janrlari" ("Genres of Uzbek classical poetry”) by Uzbek scholars O. Nosirov, S. Jamolov, M. Ziyoviddinov says about the ghazal muvashshah: "Muvashshah as a literary term is a special method - art, when the first letters in the stanzas and lines of a poem are lined up, a certain nounword is formed from their combination ${ }^{20}$. This method can be used in poems of ghazal, murabba, muhammas or other genres. The ghazal used by muwashshah is called ghazali muvashshah. Uzbek literary scholars U.Tuychiev, R.Orzibekov, Yo.Is'hakov, D.Yusupova also say that there is a ghazal muvashshah type ${ }^{21}$. But no theoretical information is given about the existence of the ghazal double muwashshah.

Chustiy has the following lines:

Assalom, ey nutqi komil shoiri nozik xayol, Nazmu nasru hajviya bobida nodir barkamol ${ }^{22}$

(Good day to you, o poet of delicate speech,

A rare master in the field of prose and poetry.)

Once the line is read in the Arabic script, we shall have an anagram that says at the beginning of the odd lines Asgrali Chrkhiyga (to be save by Charkhiy); if we read the letters at the beginning of the second lines, we get "Nbinkhon Chustidn" (from Nibinkhan Chusti). According to the Arabic script, the short vowels «a» in the words are omitted. If we replace this short vowel «a», we get the sentences "Asgarali Charkhiyga", "Nabihon Chustidan". And this situation shows that each verse creates a mutual muvashshah art. In addition, another noteworthy aspect is that the part of the ghazal that continues after the end of the muwashshah continues and reflects the art of ta'rikh (judging a particular historical event or phenomenon on the basis of abjad calculations).

\footnotetext{
${ }^{20}$ Nosirov O., Jamolov S., Ziyoviddinov M. O‘zbek klassik she'riyati janrlari. - T.: O‘qituvchi, 1979. - B. 76.

${ }^{21}$ Look: Orzibekov R. Lirikada kichik janrlar. - T.: G'afur G'ulom nomidagi Adabiyot va san'at nashriyoti, 1976; Adabiy turlar va janrlar. Uch jildlik. 2-jild. Lirika. - T.: Fan, 1992; Is'hoqov Yo. So‘z san'ati so'zligi. - T.: O‘zbekiston, 2014; Yusupova D. Aruz va mumtoz poetika asoslari. - T.: Akademnashr, 2020.

${ }^{22}$ Chustiy. Sadoqat gullari. - T.: Vneshtorgizdat, 1992. - B. 121.
} 
Boshqadan kutma deding, ey, Chustiy, bu ta'rix haqin,

Bir yuzu o'n ikkini yetmish yashar Charxiydan

$$
o l^{23} \text {. }
$$

(You said don't expect anything else, O Chusti, this ta'rikh is true,

Take one hundred and twelve from seventy-yearold Charkhi.)

Ta'rikh is "seventy-year-old Charkhi" and if we calculate it in alphabetical order and subtract 112 from it, it remains 1972. That is, the date on which Charkhi's jubilee was celebrated is 1972 . In this sense, we are in favor of conditionally calling this poem a ghazal muvashshahi tariqh. Because in this poem the features of ghazal, muvashshah and tariqh are combined. The absence of such an event in the history of our classical literature is another important factor that shows the peculiarities of the poetry of this period ${ }^{24}$.

Also, in the second half of the XX century in Uzbek ghazal creation traditions Asgarali Charkhi introduced another type of ghazal under the name of reversible ghazal. In this type of ghazal, the art of tasdir and tasbi 'are used alternately until the end of the verses, creating a wonderful melody. In particular, in the art of tasdir or radd us-sadr il-al ajuz (repetition of sadr in ajuz), the word that begins at the beginning of a stanza is repeated at the end of a stanza ${ }^{25}$. For example, matla stanza begins with the word "bakhtiyor" and ends with that word. Tasbi 'or raddul aruz ilal ibtido (repetition of aruz in the beginning) - it is said that the word that ends the first verse comes at the beginning of the second verse $^{26}$. The first verse of the matla stanza ends with the word "barqaror", and the next verse begins with the repetition of that word. These two

\footnotetext{
${ }^{23}$ Chustiy. Ibid. - B. 122.

${ }^{24}$ Rakhmonova Sh. M. Harmony of prosody and content in the Uzbek ghazals of the second half of the twentieth century. International Journal of Research in Economics and Social Sciences(IJRESS) Available online at: http://euroasiapub.org Vol. 10 Issue 10, October- 2020. - P. 42.

${ }^{25}$ Yusupova D. Aruz va mumtoz poetika asoslari. - T.:

Akademnashr, 2020. - B. 255.

${ }^{26}$ Yusupova D. Ibid. - B. 255.
}

cases can also be observed in the remaining stanzas of the returning ghazal.

\section{Bahtiyorman yashnagan yurtimda, mehrim barqaror,}

Barqaror mendek shirin umri-la hamma baxtiyor.

Ixtiyor erkini qo 'ldan yaxshi inson bermagay,

Bermagay hargiz yomon yo 'llarga vijdon ikhtiyor.

E'tibor topmoq adabdin beadablik ko'p yomon, Ko'p yomon el oldida kim bo 'lsa bee'tibor.

Bemador bo 'Ima yigitlik chog 'ida yuz tovlanib, Tovlanib yuz rangda bo 'lsang, bilki umring bemador.

Yor bo 'lur baxtu saodat mard kishiga toabad, Toabad xavfu xatarsiz, kimki mehnat birla yor.

Oshkor bo 'lganda qanday yaxshi niyat bir kuni, Bir kuni bir yomon niyat bo 'lur tez oshkor.

Intizor aylar vafosiz hamnishinlar va'dasi, Va'dasi chin yoru do 'stlar aylamaslar intizor.

Bor, yaxshilikni kasb ayla, charog 'ing o'chmagay, o'chmagay noming jahonda yaxshi kelding, yaxshi bor.

Lolazor et, Charkhiy, davroningni ko 'nglim kel, bezat,

Kel, bezat davrim jahon boricha bo 'lsin lolazor ${ }^{27}$.

The odd stanzas of this ghazal are composed of ramali musammani mahzuf, and the even stanzas of ramali musammani maqsur.

\section{Conclusion}

The following conclusions were drawn from the study of the poetry of the ghazal genre in

\footnotetext{
${ }^{27}$ Charxiy A. Qiyolab o'tdi. - T.: Akademnashr, 2010. - B. 105.
} 
Uzbek poetry of the second half of the XX century on the example of the works of Habibi, Sabir Abdullah, Chustiy, Charkhiy, Erkin Vahidov and Abdulla Aripov:

1. The lyrical genre is the main factor determining the prosody of a poetic work. When using a particular prosody, the poet must consider what genre it is intended for, as classical genres have their own prosody range.

2. Ghazal is the most widespread genre of Oriental literature and was also successfully used in poetry of the second half of the twentieth century. The poets of this period further expanded the genre possibilities of the ghazal. In the works of Chusti and Sabir Abdullah, unique examples of the ghazali qit'a emerged.

3. Charkhiy created his ghazal musajja devoted to beautiful spring in munsarihi musammani matviyi mavquf prosody which was one of the rarest illustration on the history of Uzbek literature.

4. In the poetry of this period, the genre of ghazali muvashshahi ta'rikh, which did not exist in the history of our classical literature, was also used. This poem by Chusty was written on the occasion of the 70th anniversary of Asgarali Charkhi. The ghazal form the basis of the abjad counting system in front of each one usually attributes, including the last we see there is a numerological account is defined on the basis of the number of stanzas. This event shows that by the second half of the twentieth century, the possibilities of the ghazal genre were further expanded and perfected.

5. Asgarali Charkhi introduced another type of ghazal called reversible ghazal. In this type of ghazal, the art of tasdir and tasbi 'are used alternately until the end of the stanzas.

\section{LIST OF THE USED LITERATURE:}

[1] Abdulla Sobir. Devon. - T.: Badiiy adabiyot, 1965. - B. 83.

[2] Adabiy turlar va janrlar. Uch jildlik. 2-jild. Lirika. - T.: Fan, 1992;

[3] Baranov X.K. Arabsko-russkiy slovar. M.: Nauka, 1958. - C. 721.
[4] Vohidov E. Tanlangan asarlar. - T.: "SHARQ" NMAK, 2018. - B. 400.

[5] Is'hoqov Yo. So'z san'ati so'zligi. - T.: O'zbekiston, 2014. - B. 114.

[6] Karimov N. XX asr mening taqdirimda // Jahon adabiyoti. - T., 2001. - № 1. - B. 24.

[7] Nosirov O., Jamolov S., Ziyoviddinov M. O'zbek klassik she'riyati janrlari. - T.: O'qituvchi, 1979. - B. 76.

[8] Orzibekov R. Lirikada kichik janrlar. - T.: G'afur G'ulom nomidagi Adabiyot va san'at nashriyoti, 1976;

[9] Rustamov A. Aruz haqida suhbatlar. - T.: Fan, 1972. - B. 3.

[10] To'xliev B. G'azal va uni tahlil qilish metodikasi / ALISHER NAVOIY VA XXI ASR (xalqaro ilmiy-nazariy anjuman materiallari). - T.: MASHHUR-PRESS, 2019. - B. 239.

[11] Habibiy. Devon. - T.: G`afur G‘ulom nomidagi Adabiyot va san'at nashriyoti, 1975. - B. 480.

[12] Hojiahmedov A. O`zbek aruzi lug'ati. - T.: Sharq, 1998. - B. 44.

[13] Hojiahmedov A. Furqat aruzi / Furqat ijodiyoti. - T.: Fan, 1990. - B. 83.

[14] Charxiy A. Qiyolab o'tdi. - T.: Akademnashr, 2010. - B. 107.

[15] Chustiy. Sadoqat gullari. - T.: Vneshtorgizdat, 1992. - B. 121.

[16] Chustiy. Hayotnoma. - T.: G'afur G‘ulom nomidagi Adabiyot va san'at nashriyoti, 1988. - B. 161.

[17] Yusupova D. Aruz vazni qoidalari va mumtoz poetika asoslari. - $\mathrm{T}$.: Akademnashr, 2020. - B. 261.

[18] Rakhmonova Sh. M. Harmony of prosody and content in the Uzbek ghazals of the second half of the twentieth century. International Journal of Research in Economics and Social Sciences (IJRESS) Available online at: http://euroasiapub.org Vol. 10 Issue 10, October- 2020. ISSN(o): 2249-7382 | Impact Factor: 7.077 
